anticlericalism and nationalism, the antifascists on the grounds of his internationalism, anti-imperialism, and humanitarian socialism. This struggle came to a head in the 1930s, argued Fanesi, and especially in 1932-the fiftieth anniversary of Garibaldi's death - when antifascists in Latin America launched a vigorous campaign to counter the "official" Fascist commemoration in Italy itself. In opposing this commemoration, Italian antifascists in Latin America were attempting to exploit the "myth" of Garibaldi for the first time for their own ideological purposes. Thus 1932, Fanesi argued, marked a turning point in the antifascist campaign in Latin America, away from the "defensive" posture of the 1920s and toward a spirit of reconquest. Under a Garibaldian banner, Fanesi suggested, and provoked by the Italian invasion of Ethiopia and later the Spanish Civil War, the disparate elements of Italian antifascism in Latin America were finally unified.

The Italian Club in Tampa was an ideal setting for the conference. Not only does the building itself have a rich history-the Italian immigrant organization that built it was founded in 1894-but the city itself has been home to a large and diverse immigrant population for much of its history. Throughout the meeting, Ottanelli and Gabaccia strove to integrate events with popular appeal into the proceedings. The first evening, Dirk Hoerder (Universität Bremen) and Gary Mormino (University of South Florida) moderated a panel composed of Italian, Spanish, and Cuban immigrants reflecting on the history of radicalism in Tampa. The second night featured readings from Denis Calandra's Cuban Bread, a play based on a 1931 strike waged in Ybor City and West Tampa, followed by commentary from Carina Silberstein and Nancy Green (École des Hautes Études en Sciences Sociales, Paris). Both nights' events were open to the public and complemented the more scholarly proceedings of the conference very well.

\title{
Eighty-Ninth Annual Meeting of the Organization
}

\author{
of American Historians
}

\author{
Greg Kaster \\ Gustavus Adolphus College \\ R. Todd Shuman \\ University of Illinois at Urbana-Champaign
}

"History, Memory, and Identity" was the focus of the 1996 conference of the Organization of American Historians (OAH), held in Chicago from March 28 to March 31. Together, the several panels and individual papers 
related to labor and working-class history highlighted the critical importance of identity to any full history of workers and their movements.

A panel on "Working-Class Identity and Social Democracy in PostWorld War Two America" explored the ways in which collective worker identities limited social democracy following the war, especially in the area of racial equality. Wilson Warren examined how the civil rights agenda of several Congress of Industrial Organizations (CIO) international unions was resisted at the community level. Predominantly white union locals reacted against both civil rights and communism, aspiring chiefly to protect shop-floor rights, an aim the internationals-owing to the prevailing politics of anticommunism and to "neglect"-did not always support. A basic tension between the internationals' "cosmopolitanism" and the locals" "localism," Warren argued, decisively weakened the CIO's postwar pursuit of social democracy. Roger Horowitz showed that while many working-class World War Two veterans, feeling themselves entitled to economic security in peacetime, called upon President Truman to move the federal government in a social-democratic direction, their agenda was "limited and ultimately undercut" by their view of themselves and domestic social and economic developments in nationalist rather than class terms. Race, too, was a limiting factor, as even those white veterans sympathetic to the postwar plight of their black counterparts accepted political, but not social, equality. Commentator Elizabeth Fones-Wolf applauded both papers, praising Warren's for nicely reminding labor historians that there is often a "gap" between the concerns of labor leaders and workers themselves. Turning to Horowitz, Fones-Wolf emphasized that the paper undermined the argument that veterans did not concern themselves with movements for social change in the postwar period. The current presidential campaign, she also noted, reveals the continuing ability of race to thwart progressive reform politics.

Paul Taillon and Thomas Winter addressed the themes of manhood, race, and class during the Gilded Age and Progressive Era. In his paper, Taillon challenged conventional accounts of the railroad brotherhoods as mere "bread and butter" unions. He traced their strategic "class" use of the gendered and racialized cultures and discourses of fraternalism and, after 1900 , Americanism to secure for their members not simply the working conditions and wages, but also the "manhood, respectability, and citizenship" befitting white men. Winter analyzed how, beginning in the early 1900 s, middle-class YMCA officials constructed an image of workingmen as "other" that served to affirm their own "genteel" manhood and the legitimacy of their efforts to "control" workers.

Teacher militancy was the subject of papers by Steve Golin and Susan Martin Macke. Golin contrasted the vision and strategy of politically radical Jewish members of the Newark Teachers' Union (NTU) with those of young trade-union-conscious Italian members who in the early 1960s sought to reorient the NTU from "debating" to collective bargaining. $\mathrm{He}$ also discussed how white teachers, experiencing negatively the rising num- 
ber of black students and, with them, black activists, tended to blame blacks for the decline of Newark's schools. Macke focused on what she argued was Cincinnati's radical teachers' union in the late 1970s, an argument that did not convince commentator Wayne Urban. His comments called the audience's attention to one facet of both papers that might have remained hidden - the sources. These panelists' use of oral testimonies not only made a significant contribution to the history of teacher unions, he claimed, but also demonstrated the ways in which oral history can complement traditional written sources.

Rebecca Sharpless, in "The Lady and the Field Hand: Gender Ideals and Cotton Cultivation in the Twentieth-Century South," discussed how white southerners handled the tension between the cultural ideal of domestic womanhood and the economic necessity of women's labor in the fields. Among the women themselves, she argued, some sought to keep their fieldwork out of the public eye for fear that it would disgrace them, but others saw no contradiction between such work and their status as ladies.

In the only conference panel devoted to Asian-American history, Catherine Pet examined "community formation" among the tens of thousands of Filipino nurses who migrated to the United States in the 1960s to work in inner-city hospitals that had recruited them, while Steffi San Buenaventura examined the relationship between evangelical Protestantism and Filipino laborers in Hawaii between 1910 and 1946.

The Saturday afternoon panel titled "Biography and the Study of Labor History: Three Perspectives on the Place of Leadership Studies in Today's Profession" drew a large audience. Elisabeth Perry, Steve Fraser, and David Stebenne, biographers, respectively, of Belle Moskowitz, Sidney Hillman, and Arthur Goldberg, discussed the challenges and usefulness of writing biography and what they learned from their subjects. Perry spoke of how her study of Moskowitz's Progressive reform work in New York's garment industry deepened her understanding of Progressivism as an effort to exert "rational control" over workers and employers alike. Fraser explained how his work on Hillman, president of the Amalgamated Clothing Workers, gave him greater appreciation for the important role of Hillman specifically and labor leadership generally in articulating visions "not native" to the rank and file. He used Hillman's life to critique the corporate liberal synthesis and, "paradoxically," to understand something about Hillman's constituents. For David Stebenne, a biography of Arthur Goldberg, CIO general counsel and an architect of the 1950 s "social contract" between labor and management, allowed him to write a focused and accessible account of the "rise and fall" of America's postwar political economy.

All the panelists, including David Montgomery, who supplied the comment, stressed the tremendous amount of work and time biography entails. Stebenne warned against writing the life but not the times of a subject (under pressure from a publisher) or overstating an individual's importance to social change. When successful, Montgomery observed, biography illuminates the relationship between the individual and history, which 
raises for the biographer-historian the issue of "what life to select." The lives of Moskowitz, Hillman, and Goldberg, he suggested, raise questions about the motives and experiences of Progressive women hired by "corporate welfare systems"; about how workers, too, like Progressive reformers, sought to "impose standards" (which for them meant union rules); and about how workers can become critical of union leadership but fiercely defend their unions and contracts. Both Stebenne and Montgomery agreed that biographies are the best route for labor historians if they want to reach the general reading public. Montgomery emphasized that in biographies the voice of workers is often left out, and he suggested that the size of the panel be doubled to include biographies from "both ends of the spectrum"-both workers and labor leaders.

The quality and number of papers presented at the meeting demonstrate that labor history continues to thrive. They raised questions about workers' identity, what it means to be a member of the "working class," and whether "labor history" is the history of leaders or workers. However, they often failed to consider gender, religion, and other factors which help to shape workers' identity. Although some of the papers did rely on nontraditional sources, such as oral testimony, many of the presentations would perhaps have been enhanced by the use of sources employed in the "new cultural history"-film, music, and popular literature. Since many of the papers dealt, in some fashion, with the idea of "workers' identity," the use of these sources may shed further light on the cultural creation of workingclass cultures. As labor history moves into the twenty-first century, and an age where "cultural studies" is becoming increasingly important, labor historians need to begin to recognize that factors other than class help to create working-class identity.

\title{
Council for European Studies: Toward the Social
}

\author{
and Cultural History of Capitalism
}

\author{
Christopher Schmidt-Nowara
}

Stanford University

Andrew Diamond

University of Michigan

At a conference dominated by the scholarship of political scientists, three prominent historians of modern Europe-Elisabeth Domansky, Geoff Eley, and William Sewell-gathered at a roundtable session of the Council for European Studies meeting (Chicago, March 14-17, 1996) to present 